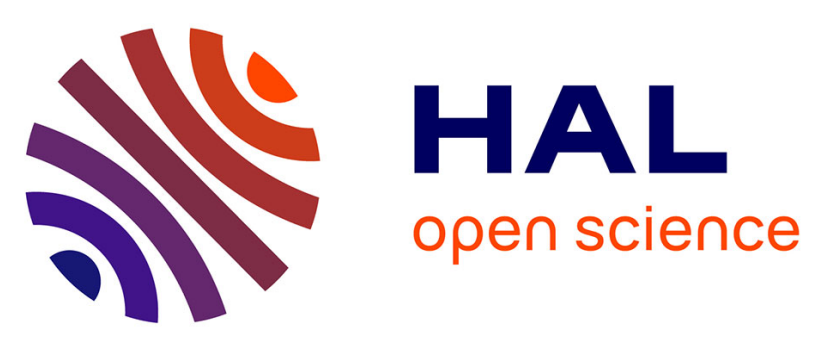

\title{
Relationships between optically assessed polyphenols and chlorophyll contents, and leaf mass per area ratio in woody plants: a signature of the carbon-nitrogen balance within leaves? \\ Sylvie Meyer, Zoran Cerovic, Yves Goulas, Pierre Montpied, Sabine \\ Demotes-Mainard, Luc Bidel, Ingrid Moya, Erwin Dreyer
}

\section{To cite this version:}

Sylvie Meyer, Zoran Cerovic, Yves Goulas, Pierre Montpied, Sabine Demotes-Mainard, et al.. Relationships between optically assessed polyphenols and chlorophyll contents, and leaf mass per area ratio in woody plants: a signature of the carbon-nitrogen balance within leaves?. Plant, Cell and Environment, 2006, 29 (7), pp.1319-1328. 10.1111/j.1365-3040.2006.01514.x . hal-02666241

\section{HAL Id: hal-02666241 https://hal.inrae.fr/hal-02666241}

Submitted on 31 May 2020

HAL is a multi-disciplinary open access archive for the deposit and dissemination of scientific research documents, whether they are published or not. The documents may come from teaching and research institutions in France or abroad, or from public or private research centers.
L'archive ouverte pluridisciplinaire HAL, est destinée au dépôt et à la diffusion de documents scientifiques de niveau recherche, publiés ou non, émanant des établissements d'enseignement et de recherche français ou étrangers, des laboratoires publics ou privés. 


\title{
Relationships between optically assessed polyphenols and chlorophyll contents, and leaf mass per area ratio in woody plants: a signature of the carbon-nitrogen balance within leaves?
}

\author{
S. MEYER ${ }^{1}$, Z. G. CEROVIC ${ }^{1}$, Y. GOULAS ${ }^{2}$, P. MONTPIED ${ }^{3}$, S. DEMOTES-MAINARD ${ }^{4}$, L. P. R. BIDEL ${ }^{4}$, I. MOYA ${ }^{2}$ \& \\ E. DREYER ${ }^{3}$
}

${ }^{1}$ Equipe Biospectroscopie Végétale, Laboratoire d'Ecologie Systématique et Evolution, UMR 8079, Bât. 362, Université Paris Sud, 91405 Orsay Cedex, ${ }^{2}$ Equipe Fluorescence et Télédétection, Laboratoire de Météorologie Dynamique, CNRS-UMR 8359, Ecole Polytechnique, 91128 Palaiseau Cedex, ${ }^{3}$ UMR INRA-UHP1137 Ecologie et Ecophysiologie Forestières, 54280

Champenoux and ${ }^{4} I N R A$, UMR A-462 INRA/INH/Université SAGAH (Sciences Agronomiques Appliquées à l'Horticulture), 42 rue Georges Morel BP60057, 49071 Beaucouze Cedex, France

\begin{abstract}
Chlorophyll (Chl) and epidermal polyphenol (EPhen) contents were estimated in vivo using two optical leaf-clips, SPAD-502 and Dualex, respectively. The area-based measurements were transformed into mass-based data by taking into account the leaf dry mass per area (LMA). Measurements were performed on forest trees and on saplings grown under controlled conditions. While LMA increased with irradiance along a vertical transect in a beech canopy or in saplings grown under different and increasing irradiance levels, mass-based EPhen $\left(\right.$ EPhen $\left._{\mathrm{m}}\right)$ increased, whereas mass-based $\mathrm{Chl}\left(\mathrm{Chl}_{\mathrm{m}}\right)$ decreased. This was a signature of a gradual switch of investment from protein into polyphenol production. A similar signature was obtained in saplings grown on nitrogen-deficient soil with respect to fertilized controls. However, nitrogen effects remained moderate compared to irradiance-induced effects. $\mathbf{E P h e n}_{\mathrm{m}}$ and $\mathrm{Chl}_{\mathrm{m}}$ both declined with plant ageing-induced increases in LMA, under all tested growth conditions. This was a signature of an accumulation of dry matter that diluted $\mathrm{Chl}$ and EPhen. The described competition between $\mathrm{Chl}$ and EPhen in leaves fits well with the predictions of the Protein Competition Model (PCM), that is, that the total leaf mass-based polyphenols content $\left(\right.$ Phen $\left._{t}\right)$ is controlled by the competition between protein and polyphenol biosynthetic pathways and its metabolic regulation.
\end{abstract}

Key-words: acclimation to light; chlorophyll; Dualex; epidermal polyphenols; leaf; LMA; nitrogen; phenylpropanoids; SPAD.

Abbreviations: Chl, chlorophyll; $\mathrm{Chl}_{\mathrm{a}}$, area-based chlorophyll content; $\mathrm{Chl}_{\mathrm{m}}$, mass-based chlorophyll content; EPhen, epidermal polyphenols; EPhen $_{a}$, area-based

Correspondence: S. Meyer. Fax: +3316915 7238; e-mail: sylvie.meyer@ese.u-psud.fr epidermal polyphenols content; EPhen $_{\mathrm{m}}$, mass-based epidermal polyphenol content; LMA, leaf dry mass per area; $\mathrm{N}_{\mathrm{m}}$, mass-based leaf nitrogen content; PAL, phenylalanine ammonia lyase; PCM, Protein Competition Model; Phen, polyphenols; Phen, total leaf mass-based polyphenols content; Prot $t_{t}$, total leaf mass-based protein content; SLA, specific leaf area (=1/LMA).

\section{INTRODUCTION}

Most environmental conditions that induce phenotypic plasticity in leaves involve variation in carbon and nitrogen economy. It is known that high irradiance and soil-nitrogen deficiency stimulate production and accumulation of polyphenols (Phen) and reduce mass-based protein content (see Koricheva et al. 1998 for a review). Phen are carbonrich compounds that contain about $30 \%$ (on a mass basis) more carbon than proteins (Poorter 1994). They accumulate in vacuoles or cell walls and can enhance leaf density (Witkowski \& Lamont 1991). On the other hand, proteins are the main leaf nitrogen compounds, the synthesis of which is required for growth, photosynthesis and homeostasis (see Jones \& Hartley 1999).

The Carbon Nutrient Balance (CNB) and Growth Differentiation Balance (GDB) hypotheses are models frequently used to predict the phenotypic variations in leaf Phen in woody plants (Koricheva et al.1998). Phen fit tightly with these hypotheses, better than any other class of secondary compounds, like terpenoids or hydrolysable tannins (Koricheva et al.1998). This is probably due to the fact that proteins and Phen share a common precursor, Lphenylalanine (PHE) (Margna 1977). Jones \& Hartley (1999) proposed the Protein Competition Model (PCM), which takes into account this competition between protein and Phen biosynthetic pathways and its metabolic control in order to predict total leaf mass-based Phen contents $\left(\mathrm{Phen}_{\mathrm{t}}\right)$. The PHE allocation to Phen is controlled by phenylalanine ammonia lyase (PAL) activity and expression, 
and both protein synthesis and Phen metabolism compete for limiting PHE (cf. Jones \& Hartley 1999 and the references therein). In addition, total leaf mass-based protein content $\left(\right.$ Prot $\left._{t}\right)$ and Phen $_{t}$ may be modulated by leaf dry matter content. An increase in leaf dry matter (due for instance to starch and cellulose accumulation) passively dilutes both proteins and Phen, whereas a decrease concentrates them. Many cases reported in the literature (cf. Bryant, Chapin \& Klein 1983, e.g.) about constitutive and inducible Phen confirmed the validity of PCM. Jones \& Hartley (1999) cited about 30 confirming studies dealing with light and nutrient effects. Recently, Scheible et al. (2004) performed a transcriptome analysis on Arabidopsis under different nitrogen regimes and demonstrated that protein synthesis is tightly coordinated with Phen metabolism, which supports the main hypothesis of the PCM (Jones \& Hartley 1999). A nitrate addition induced the genes for amino acid biosynthesis and repressed the shikimate pathway, the expression of PHE and many genes involved in hydroxycinnamic acid and flavonoid metabolism (Scheible et al. 2004). In this case, PHE expression was more coordinated with Phen metabolism than with protein metabolism (Scheible et al. 2004). The tight regulatory link between protein and Phen metabolism might rather be the supply of carbon skeletons like erythrose-4-phosphate, which is a precursor for the shikimate pathway and primary metabolism (Henkes et al. 2001). Actually, PCM predictions do not depend on the identity of the regulatory link between carbon and nitrogen metabolism (Jones \& Hartley 1999). The physiological interest of the PCM is to predict the effect of changing environmental resources on the result of the coordination between primary and secondary metabolisms. This leads to interpreting leaf phenotypes in terms of the balance between primary and secondary metabolisms, which can be an indicator of the plant protective or growth strategy in a given habitat (Herms \& Mattson 1992).

One way to monitor acclimation responses to changing microenvironment conditions and test for their impact on the Phen/protein balance may rely on optical methods usable in the field. Chlorophyll (Chl)-binding protein complexes are of special interest because their chromophores, Chl $a$ and $b$, can be easily detected by optical techniques, for instance with a Chl meter like the Minolta SPAD-502 (hereafter SPAD) (Peng et al. 1993; Markwell, Osterman \& Mitchell 1995). According to Evans (1989b) and Evans \& Seemann (1989), $50-80 \%$ of leaf nitrogen is allocated to photosynthetic proteins, $16 \%$ of which is made of nitrogen. The range of Prot $t_{t}$ for woody plant leaves is 5-22\% of dry mass (Poorter 1994). Therefore, mass-based chlorophyll content $\left(\mathrm{Chl}_{\mathrm{m}}\right)$ can be regarded as an index for Prot ${ }_{\mathrm{t}}$. However, the proportionality between $\mathrm{Chl}_{\mathrm{m}}$ and mass-based leaf nitrogen content $\left(\mathrm{N}_{\mathrm{m}}\right)$ may vary, because of the modifications of nitrogen partitioning among photosynthetic proteins demonstrated in response to light, nitrogen and among species (Hikosaka \& Terashima 1995; Evans \& Poorter 2001; Takashima, Hikosaka \& Hirose 2004; Coste et al. 2005).

Leaf Phen content can be optically estimated with a new portable leaf-clip, the Dualex (Force-A, Orsay, France)
(Goulas et al. 2004; Cartelat et al. 2005). Phen include hydroxycinnamic acids, flavonoids, condensed tannins and lignin. Dualex measures in situ epidermal Phen (EPhen) content, mainly flavonoids, by comparing Chl fluorescence induced by UV-A $(375 \mathrm{~nm})$ to that induced by red light (650 nm, reference). It is worth noting that it is very difficult to estimate $\mathrm{Phen}_{\mathrm{t}}$ in leaves because they include soluble and insoluble molecules in different cell compartments and their quantity depends on the species. Water-soluble glycosylated flavonoids are mainly stored in epidermal cell vacuoles, whereas hydroxycinnamic acids are bound to cell walls. Phen serve multiple functions, depending on their location in the leaf, like chemical defence against herbivores or pathogens, protection against ultraviolet (UV) and oxidative stress or signals for communication (see Wink 1999 for a review). The synthesis of Phen is enhanced when carbon is produced in excess compared to the metabolic demand for growth in a given environment (Bryant et al. 1983; Waterman, Ross \& McKey 1984). Their production is constitutive, according to the leaf carbon economy, or inducible by biotic or abiotic stresses. Flavonoids induce a higher construction cost (g glucose/g compounds) compared to hydroxycinnamic acids (Gershenzon 1994). In woody species, soluble Phen, condensed tannins and lignins constitute about $2-11,1-30$ and $4-19 \%$ of the leaf dry matter, respectively (Waterman et al. 1984; Mole, Ross \& Warterman 1988; Poorter 1994; Lavola et al. 2000; Riipi et al. 2002; Tegelberg, Julkunen-Tiitto \& Aphalo 2004). Dualex measurements yielded a reliable estimate of total soluble Phen in wheat leaves (Cartelat et al. 2005). However, whether Dualex measurements are representative of total leaf Phen, especially in woody species, remains still an open question. Nevertheless, the presently available chemical or optical methods all present limitations for the assessment of leaf Phen accurately. Although total $\mathrm{Chl}$ and epidermal flavonoids represent a small fraction of leaf dry mass, about 0.5-1.5 (Niinemets, Kull \& Tenhunen 2004) and 2.0-3.5\% (Lavola et al. 2000), respectively, their mass-based content is strongly dependent of leaf nitrogen and carbon economy (Evans 1989a; Evans \& Seemann 1989; Koricheva et al. 1998; Cartelat et al. 2005).

Optical measurements provide estimates of area-based pigment contents. Changes in area-based constituents can be linked to carbon and nitrogen allocation if changes in leaf dry mass per area (LMA) are taken into account. We estimated LMA and investigated the correlations between SPAD and Dualex measurements with LMA in the case of contrasting irradiance levels, nitrogen deficiency and plant ageing in forest trees or in saplings grown under controlled conditions. The aims of the experiments were: (1) to quantify $\mathrm{Chl}$ and EPhen contents in woody plants using two optical non-invasive methods; (2) to assess in vivo the potential trade-offs between investment into Chl (surrogate for leaf proteins) and into EPhen (surrogate for leaf Phen); (3) to test for interspecific differences in these responses; and (4) to check whether the observed phenological plasticity induced by irradiance or by nitrogen availability could be interpreted in the framework of one of the differ- 
ent models that were proposed for the relative allocation of nitrogen and carbon to protein versus Phen synthesis.

\section{MATERIALS AND METHODS}

\section{Plant material and experiment design}

Three experiments were performed at four locations and with several woody plant species. The first experiment (Exp 1) was performed in the field making profit of a vertical transect within a beech canopy. The second experiment (Exp 2) was performed with saplings of four forest tree species grown under different irradiance levels. The third experiment (Exp 3) was performed with saplings of four species of horticultural interest supplied with high or low nitrogen under natural irradiance.

Exp 1 was performed at the experimental long-term ecosystem monitoring site of Hesse (France, $48^{\circ} 45^{\prime} \mathrm{N}, 6^{\circ} 20^{\prime} \mathrm{E}$, altitude of $255 \mathrm{~m}$ ) in a beech forest (Granier, Pilegaard \& Jensen 2002). Four sets of measurements were made along a vertical transect in the canopy of 30-year-old neighbouring beech trees (Fagus sylvatica L.), at monthly intervals throughout the summer of 2001. About 20 (or 10) fully expanded leaves were sampled at 5 (or 10) different heights and three SPAD and two Dualex measurements (abaxial and adaxial faces) were performed on each leaf. The leaves were then sampled for nitrogen and $\mathrm{Chl}$ content, and area and dry mass measurements (100 leaves total per sampling). In Exp 2, 2-year-old birch saplings (Betula pendula Roth., pioneer and shade-intolerant), beech (Fagus sylvatica L., late-successional and shade-tolerant), ash (Fraxinus excelsior L., post-pioneer and intermediate in shade tolerance) and sycamore (Acer pseudoplatanus L., post-pioneer and intermediate in shade tolerance) were used. They had been grown at INRA, Champenoux, France, for 2 years in $10 \mathrm{~L}$ pots containing a blond peat/sand mixture $(1 / 2, \mathrm{v} /$ $\mathrm{v})$. The pots were fertilized every year with $8 \mathrm{~g} \mathrm{~L}^{-1}$ of Nutricote 100 slow-release fertilizer $\left(13 / 13 / 13, \mathrm{~N} / \mathrm{P} / \mathrm{K}^{+}\right)$(Fertil, Le Syndicat, France) at the beginning of May and during mid-July. The drip irrigation of each individual pot provided water to adequate field capacity twice a day. Five saplings were used per species. Shade was imposed with a neutral sheet (polyester + aluminium, OLS Ludvig Svensson International, Hellevoestluis, the Netherlands) providing approximately $100,36,16$ and $4 \%$ of transmitted incident photosynthetic active radiation (PAR). The microclimate below the screens was monitored using a mobile weather station [pyranometer (Skye SP 1110, Skye Instruments, Powys, UK); Pt100 platinum-resistance thermometer (Pico Technology Ltd, St Neots, UK); ventilated psychrometer with a second Pt100; measuring frequency $0.1 \mathrm{~Hz}$ with a Campbell 21X data logger (Campbell Scientific, Logan, UT, USA) and direct computation of 30 min means]. During August 2000, the saplings were sampled for optical measurements, nitrogen and Chl quantitation and LMA determination. Ten fully expanded leaves from the current year growth flush were used per treatment and per species. For ash, measurements were made on the terminal leaflet.
Three SPAD measurements were performed on each leaf, and three Dualex measurements on each side of each leaf. The leaves were then sampled for nitrogen and Chl contents and area and dry mass measurements.

In Exp 3, four woody species of horticultural interest, Lagerstroemia indica cv. Red Imperator (deciduous), Callicarpa bodinieri cv. Profusion (deciduous), Robinia pseudoacacia cv. Casque Rouge (deciduous) and Viburnum tinus cv. Macrocarpa (evergreen) were obtained from commercial nurseries where they had been propagated and grown outdoors for 1 year. During March 2002, these were transplanted into $4 \mathrm{~L}$ containers with a peat/perlite mixture (50/50, v/v, pH 6.4). The plants were placed outdoors at Angers (France, latitude $47^{\circ} 30^{\prime} \mathrm{N}$, longtitude $0.35^{\circ} \mathrm{W}$ and altitude of $56 \mathrm{~m}$ ) at a density of six plants per $\mathrm{m}^{-2}$. Diseases and insects were controlled by pesticide application. The plants were supplied with drip irrigation, as a function of the evaporative demand calculated at an hourly step. Fertilization was supplied by nutrient solution brought with irrigation. From 30 April to 2 June 2002, all the plants received a complete nutrient solution $(5.59,3.45,2.94,4.64$, 2.36, 3.94 and 0.78 mequiv $\mathrm{L}^{-1}$ of $\mathrm{N}^{-\mathrm{NO}_{3}}, \mathrm{P}, \mathrm{S}, \mathrm{Ca}, \mathrm{Mg}, \mathrm{K}$ and $\mathrm{Na}$, respectively), with nitrogen supplied only as nitrate. Experimental treatments involved contrasted Nfertilization regimes in June and July. From 3 June to 31 July 2002, the plants received either a nutrient solution with a high nitrogen concentration $(6.29,1.24,3.90,2.94,4.64$, 2.36, 3.95 and 0.78 mequiv $\mathrm{L}^{-1}$ of $\mathrm{N}^{-\mathrm{NO}_{3}}, \mathrm{~N}-\mathrm{NH}_{4}, \mathrm{P}, \mathrm{S}, \mathrm{Ca}$, $\mathrm{Mg}, \mathrm{K}$ and $\mathrm{Na}$, respectively), or a nutrient solution with a low nitrogen concentration, the nitrogen coming exclusively from tap water $(0.25,3.45,5.64,2.64,4.64,2.36,3.94$ and 0.78 mequiv $\mathrm{L}^{-1}$ of $\mathrm{N}-\mathrm{NO}_{3}, \mathrm{P}, \mathrm{S}, \mathrm{Cl}, \mathrm{Ca}, \mathrm{Mg}, \mathrm{K}, \mathrm{Na}$, respectively). 3 June 2002 was considered as the beginning of the experimental treatments and noted as day zero. For each species, the treatments were arranged in a complete randomized design with three replicates. Each species was grown on an individual plot of 12 rows, and the border rows were avoided when sampling to minimize edge effects. For each species, three replicates were performed each week in June and July 2002. Two plants per replicate were sampled. Ten leaves (young leaves already extended and exposed to direct sunlight) per plant were used for analysis. Plant age, but not leaf age, varied with sampling date. Optical measurements were performed on the same sample of 20 leaves per replicate on which LMA was measured. Two Chl measurements were performed on each leaf. Four Dualex readings were taken per leaf, two each on the adaxial and abaxial sides. The leaves were then sampled for nitrogen and $\mathrm{Chl}$ contents and area and dry mass measurements.

\section{Leaf $\mathrm{Chl}$ and nitrogen contents and leaf mass per area}

For the calibration of SPADs and for the direct quantification of Chl, two similar methods were used. In the first case, 10 leaf discs (4.0 mm diameter) were sampled from each leaf. The total sampled surface was $1.26 \mathrm{~cm}^{2}$ per leaf. The discs were frozen at $-80^{\circ} \mathrm{C}$ if not used immediately. Extrac- 
tion was performed in $5 \mathrm{~mL}$ of $95 \%$ ethanol at $70{ }^{\circ} \mathrm{C}$ for $30 \mathrm{~min}$ in a sealed tube. After cooling, the transmittance of the extract was measured with a Lambda 3 Perkin-Elmer spectrophotometer (Courtaboeuf, France) at 664.2 and $648.6 \mathrm{~nm}$, and the Chl $a$ and $b$ concentrations were calculated according to Lichtenthaler (1987). The second method consisted of extracting $2 \mathrm{~cm}^{2}$ leaf discs in dimethylsulfoxide (DMSO) at $70^{\circ} \mathrm{C}$, according to the procedure of Barnes et al. (1992). The error in estimating Chl content from the calibration relationship was less than $10 \%$. A calibration relationship was established for each species.

In the Exp 1 through 3, leaf nitrogen concentration was measured following the method of Dumas. The samples were dried at $60{ }^{\circ} \mathrm{C}$, weighed and ground. An aliquot of the powder was combusted in an elemental analyser (NCS2500 EA/NA 1110, CE instrument Thermo Quest, Milano, Italy, in Exp 1 and 2, and Flash EA 1112, Thermo Electron S.A., Courtaboeuf, France, in Exp 3). This method measures the total $\mathrm{N}$ content, including nitrate.

\section{Optical estimation of leaf $\mathrm{Chl}$ and Phen}

Chl was estimated using the Minolta SPAD-502 Chl meter. A calibration curve was established for each experiment, which involved a different Chl meter (Markwell et al. 1995; Cartelat et al.2005). The SPAD values were then converted into area-based $\mathrm{Chl}$ content $\left(\mathrm{Chl}_{\mathrm{a}}\right)$. $\mathrm{Chl}_{\mathrm{m}}$ was obtained by dividing $\mathrm{Chl}_{\mathrm{a}}$ by LMA $\left(\mathrm{Chl}_{\mathrm{a}}=\mathrm{Chl}_{\mathrm{m}} * \mathrm{LMA}\right)$.

EPhen were estimated using a Dualex device according to Cartelat et al. (2005). The Dualex readings of each side of the leaf were summed to estimate the total area-based EPhen content $\left(\right.$ EPhen $\left._{\mathrm{a}}\right)$. EPhen $\mathrm{a}$ is expressed in molar units of quercetin (aglycone) equivalents, calculated from Dualex-derived absorbance, using the molar extinction coefficient $(\varepsilon)$ of $20 \mu \mathrm{mol}^{-1} \mathrm{~cm}^{2}\left(20 \mathrm{~mm}^{-1} \mathrm{~cm}^{-1}\right)$ at $375 \mathrm{~nm}$ :

EPhen $_{\mathrm{a}}=($ adaxial + abaxial Dualex measurements $) / \varepsilon$

Quercetin derivatives are by far the most universally distributed flavonoids (Bate-Smith 1962) and are, with myricetin, the major flavonoid family in silver birch (Riipi et al. 2002; Tegelberg et al. 2004). Moreover, the $\varepsilon$ of flavonoids are very close (Cerovic, unpublished results). Mass-based EPhen content $\left(\right.$ EPhen $\left._{\mathrm{m}}\right)$ was obtained by dividing EPhen

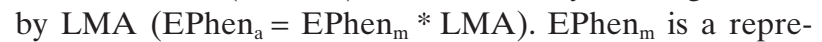
sentative (surrogate) of total leaf Phen expressed in leaf dry mass basis, like $\mathrm{Chl}_{\mathrm{m}}$ that is a representative (surrogate) of total leaf protein, although it is present only in chloroplast. $\mathrm{EPhen}_{\mathrm{m}}$ is a proportion of a leaf mass allocated to EPhen expressed in equivalent micromole aglycon quercetin per gram of leaf dry matter. It is worth noting that Kolb \& Pfündel (2005) show that a heterogeneous distribution of UV-A absorbers in epidermal cells lead to an optical sieve effect, that would affect only very high EPhen ${ }_{\mathrm{a}}$ levels.

\section{Statistical analysis}

Covariance analyses were performed using Igor Pro 4 (WaveMetrics Inc., Lake Oswego, OR, USA) and Statistica
6 (StatSoft Inc., Maison-Alfort, France). The relationships between optical measurements and LMA were investigated using correlation and regression procedures. Nitrogen treatment, species and plant age (sampling date) effects were tested in Exp 3 using a multivariate analysis of variance [(ANOVA); using a general linear modelling (GLM) procedure]. The sampling size was $n=32,16$ and 8 replicates for nitrogen treatment, species and plant age effects, respectively. The analysis of covariances (ANCOVAs) were performed to test species effect on LMA versus light intensity, $\mathrm{Chl}_{\mathrm{a}}$ versus LMA, $\log \mathrm{Chl}_{\mathrm{m}}$ versus $\operatorname{logLMA}$ and $\mathrm{EPhen}_{\mathrm{a}}$ versus LMA relationships in Exp 2, and to test the nitrogentreatment effect on $\mathrm{EPhen}_{\mathrm{m}}$ with $\mathrm{Chl}_{\mathrm{m}}$ as covariable in Exp 3 .

\section{RESULTS}

\section{Effect of light microenvironments}

The LMA increased from the bottom $\left(25 \mathrm{~g} \mathrm{~m}^{-2}\right)$ to the top $\left(120 \mathrm{~g} \mathrm{~m}^{-2}\right)$ of the canopy of $F$. sylvatica with increasing light availability like commonly described (Niinemets 1995; data not shown). This indicates a gradual thickening of palisade parenchyma and an increase in leaf density (Hanson 1917; Witkowski \& Lamont 1991; Liakoura, Bornman \& Karabourniotis 2003; Aranda et al. 2004; Niinemets et al. 2004). The moderate but significant increase in $\mathrm{Chl}_{\mathrm{a}}$ with LMA (Fig. 1a) was ascribed to an increase in LMA, which largely compensated for the decrease in $\mathrm{Chl}_{\mathrm{m}}$ (Fig. 1b). $\mathrm{Chl}_{\mathrm{m}}$ decreased with LMA according to a curvilinear relationship from 1.0 to $0.2 \%$ of leaf dry matter from the bottom to the top of the canopy (Fig. 1b). The logarithmic transforms of $\mathrm{Chl}_{\mathrm{m}}$ and LMA were tightly and linearly correlated $\left(r=0.954, \quad P<0.00001, \quad n=79, \quad \log \mathrm{Chl}_{\mathrm{m}}=2.07-\right.$ $0.080 * \log$ LMA). However, $\mathrm{N}_{\mathrm{m}}$ remained almost constant

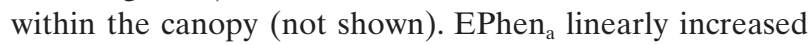
with LMA and were tightly correlated to it $(r=0.980$, $n=82, P<0.0001)$. The LMA accounted for $96 \%$ of EPhen variation (Fig. 1c). EPhen $_{\mathrm{m}}$ curvilinearly increased with LMA (Fig. 1d). 1/EPhen ${ }_{\mathrm{m}}$ and SLA (=1/LMA) were linearly and tightly correlated $(r=0.823, n=82, P<0.001,1$ / EPhen $\left._{\mathrm{m}}=0.045+1.54 * \mathrm{SLA}\right)$, and $68 \%$ of $1 / \mathrm{EPhen}_{\mathrm{m}}$ variation was ascribed to SLA. The increase of EPhen ${ }_{a}$ resulted therefore, both from increased LMA and increased EPhen $_{\mathrm{m}}$.

Exp 2 produced similar results for saplings of four tree species submitted to different irradiance levels during growth (Figs 2 \& 3). LMA increased with incident irradiance in every species (Fig. 2) showing that irradianceinduced plasticity was of similar extent independently of the degree of shade tolerance of the species. Like in Exp 1, $\mathrm{Chl}_{\mathrm{a}}$ increased moderately but significantly with LMA ( $P=$ 0.0263 ) (Fig. 3a). No species effect was observed on the slope $(P=0.1545)$, but the Y-intercept was significantly different $(P<0.0001)$, and $F$. sylvatica displayed consistently lower values than the other species. $\mathrm{Chl}_{\mathrm{m}}$ decreased with LMA in all species $(r=0.889, n=16, P<0.0001$, after logarithmic transformation, $\log C h l_{m}=2.00-0.725 * \operatorname{LogLMA}$, Fig. 3b), revealing in all cases an acclimation by adjusting 


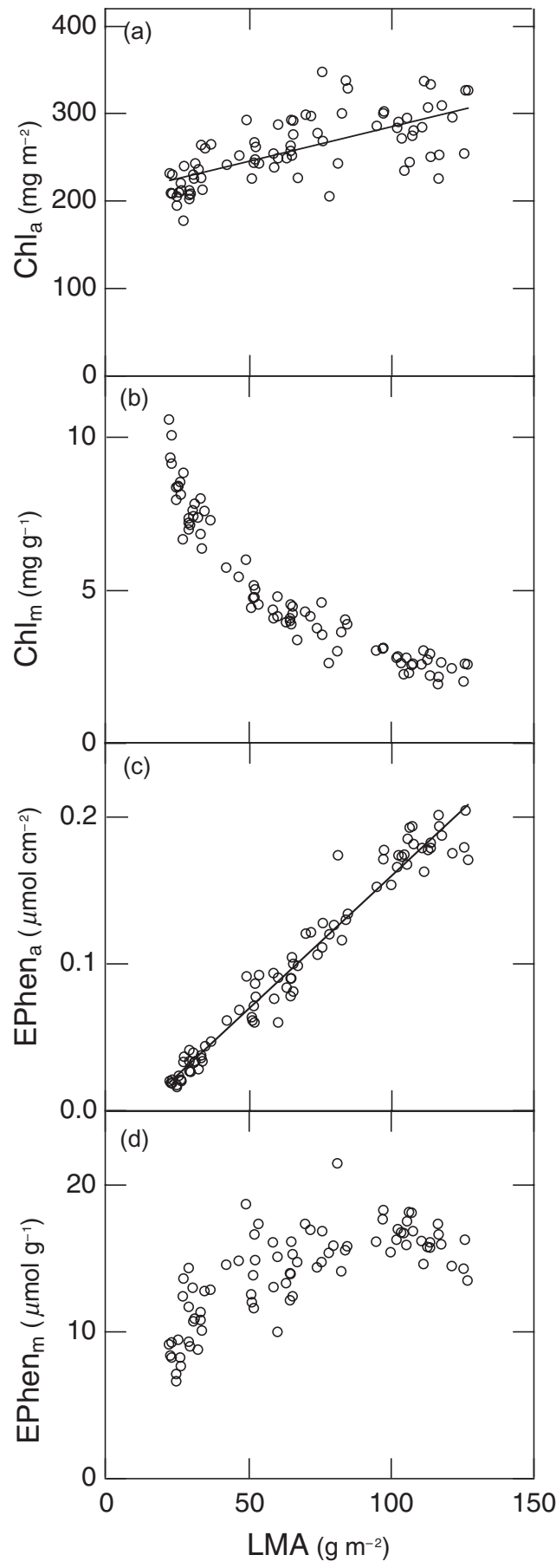

Figure 1. Relationship between optical measurements of Chl $(\mathrm{a}, \mathrm{b})$ and EPhen $(\mathrm{c}, \mathrm{d})$, and LMA in the canopy of Fagus sylvatica. Data are from Exp 1. (a,c) Area-based data derived directly from optical measurements. (b,d) Mass-based data obtained after dividing area-based values by LMA. Regression equations are: (a) $\mathrm{Chl}_{\mathrm{a}}=206.5+0.790 * \mathrm{LMA}, r^{2}=0.46, P<0.0001, n=82$ and (c) EPhen $_{\mathrm{a}}=0.002 *$ LMA $-0.020, r^{2}=0.96, P<0.0001, n=82$.

leaf $\mathrm{Chl}_{\mathrm{m}}$ to growth-light intensity. There was no difference among species in the slope of the relationship with LMA $(P=0.0920$, after logarithmic transformation), but differences in the Y-intercept were significant $(P<0.0001$, with lowest values recorded again in F. sylvatica). EPhen ${ }_{a}$ linearly increased with LMA in the four species $(P<0.0001$, Fig. 3c). The relationships could not be distinguished among species $(P=0.0815$ for the slope, and $P=0.0596$ for the Y-intercept). Therefore, all data were pooled for further analysis. The correlation was very tight, and LMA accounted for $78 \%$ of EPhen ${ }_{a}$ variation. The slope and the Y-intercept of the regression equation were close to those obtained in Exp 1 (see legends of Figs 1 \& 3). EPhen ${ }_{\mathrm{m}}$ significantly varied with LMA in B. pendula $(P=0.0357$, $n=4)$, but not in F. sylvatica $(P=0.4621, n=4)$, F. excelsior $(P=0.2142, n=4)$ and A.pseudoplatanus $(P=0.7594$, $n=4)$. Despite the interspecific difference in $\mathrm{EPhen}_{\mathrm{m}}$, the relationship between $\mathrm{EPhen}_{\mathrm{a}}$ and LMA was relatively uniform, showing that $\mathrm{EPhen}_{\mathrm{a}}$ variations resulted from LMA variations. The shade-intolerant pioneer species B. pendula presented a high and almost constant EPhen $\mathrm{m}_{\mathrm{m}}$. These EPhen $_{\mathrm{m}}$ values were also higher than in Exp 1, possibly related to lower LMA in the saplings. Intermediate (A. pseudoplatanus, F. excelsior) and late (F. sylvatica) successional species acclimated to the light intensity by modulating EPhen $_{\mathrm{m}}$ to a larger extent than did B. pendula with nevertheless smaller values.

In Fig. 4, we plotted $\mathrm{EPhen}_{\mathrm{m}}$ against $\mathrm{Chl}_{\mathrm{m}}$ data from Exp 1 and 2 to investigate if the variation in leaf chemical composition in response to light was unique. $\mathrm{EPhen}_{\mathrm{m}}$ was negatively correlated to $\mathrm{Chl}_{\mathrm{m}}, \mathrm{Chl}_{\mathrm{m}}$ accounting for 63,75 and $47 \%$ of variations in EPhen $_{\mathrm{m}}$, for F. sylvatica in Exp 1 (Fig. 4a), B. pendula in Exp 2 and F.excelsior in Exp 2 (Fig. 4b), respectively. The correlation was not significant for F. sylvatica and A. pseudoplatanus in Exp 2. The pioneer and fast-growing species (B.pendula) displayed a much

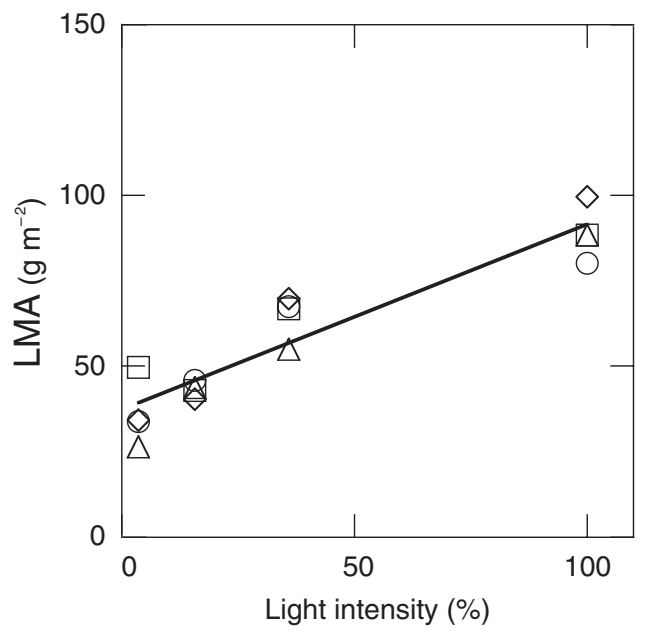

Figure 2. Relationship between LMA and irradiance (expressed as a fraction of external incident irradiance) in Fagus sylvatica $(\bigcirc)$, Betula pendula $(\triangle)$, Acer pseudoplatanus $(\diamond)$ and Fraxinus excelsior $(\square)$ saplings grown in a greenhouse. Data are from Exp 2 , with $n=10$ for each point. An analysis of covariance (ANCOVA) showed no difference among species in the slope $(P=0.4634)$, but a difference in the Y-intercept $(P<0.0001)$ and a significant effect of the covariable $(P<0.0001)$. Regression equation after pooling the four species $(n=16)$ is: $\mathrm{y}=29.51+72.2 * \mathrm{x}, r^{2}=0.87, P<0.0001$. 


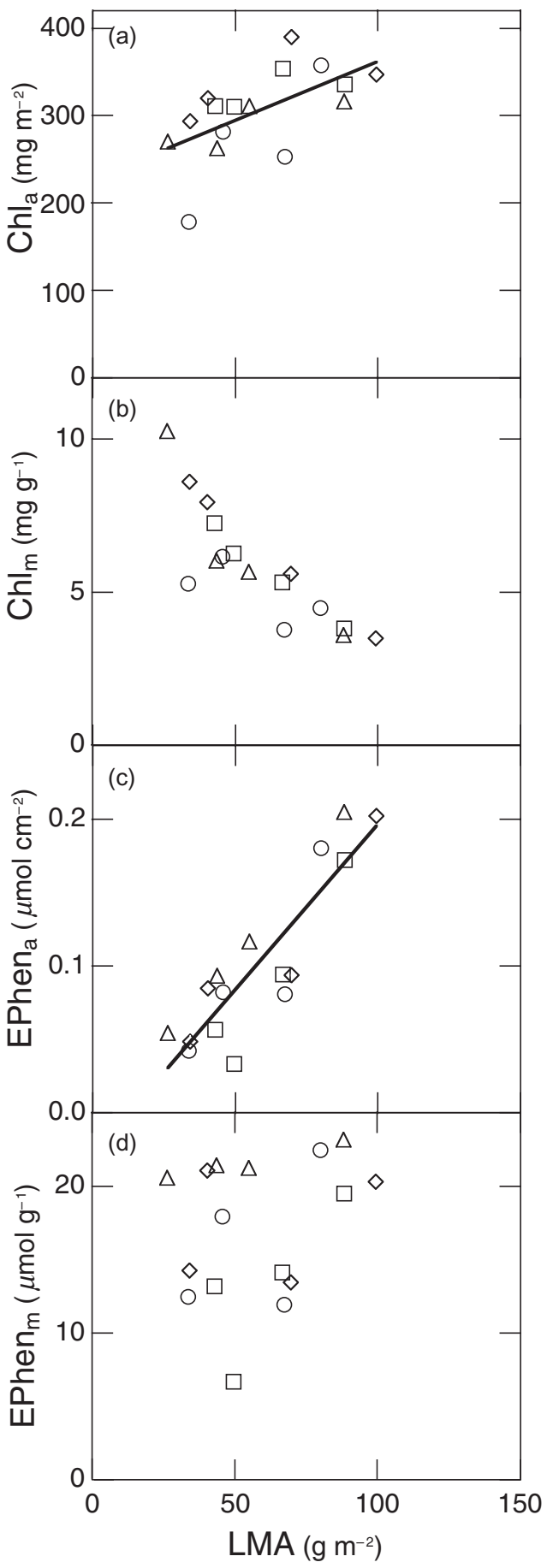

Figure 3. Relationship between the optical measurements of Chl $(\mathrm{a}, \mathrm{b})$ and EPhen $(\mathrm{c}, \mathrm{d})$, and LMA for tree saplings grown under different levels of irradiance $(\bigcirc$, Fagus sylvatica; $\triangle$, Betula pendula; $\diamond$ Acer pseudoplatanus; $\square$ Fraxinus excelsior) grown under different irradiations (Exp 2). (a,c) Area-based data derived directly from optical measurements. (b,d) Mass-based data obtained after dividing optical measurements by LMA. Regression equations after pooling the four species $(n=16)$ are: (a) $\mathrm{Chl}_{\mathrm{a}}=252.8+1.49 *$ LMA, $r^{2}=0.31, P=0.0255$ and $(\mathrm{c})$ EPhen $_{\mathrm{a}}=0.0025 *$ LMA $-0.0287, r^{2}=0.78, P<0.0001$. larger value of $\mathrm{EPhen}_{\mathrm{m}}$ with respect to $\mathrm{Chl}_{\mathrm{m}}$ than all other species.

\section{Effect of nitrogen deficiency, species and plant ageing}

In Exp 3, nitrogen, species and plant ageing significantly affected LMA and $\mathrm{Chl}_{\mathrm{a}}, \mathrm{Chl}_{\mathrm{m}}, \mathrm{EPhen}_{\mathrm{a}}$ and $\mathrm{EPhen}_{\mathrm{m}}$ (Table 1). LMA generally increased as the plant aged and/ or nitrogen availability declined (Fig. 5). At the beginning of the treatment, LMA was highest in Viburnum. Lagerstroemia was the species exhibiting the largest increase in LMA under nitrogen deficiency throughout the experiment (Fig. 5b). The slight increase of $\mathrm{Chl}_{\mathrm{a}}$ with LMA was ascribed to the increase of LMA, which compensated for and overtopped the decrease in $\mathrm{Chl}_{\mathrm{m}}$ (Fig. 6a \& b). The increase of EPhen $_{\mathrm{a}}$ with LMA was not linear, because EPhen $_{\mathrm{m}}$ sharply decreased with LMA (Fig. 6c \& d). Figure 6 shows that the dry mass invested in Chl and EPhen

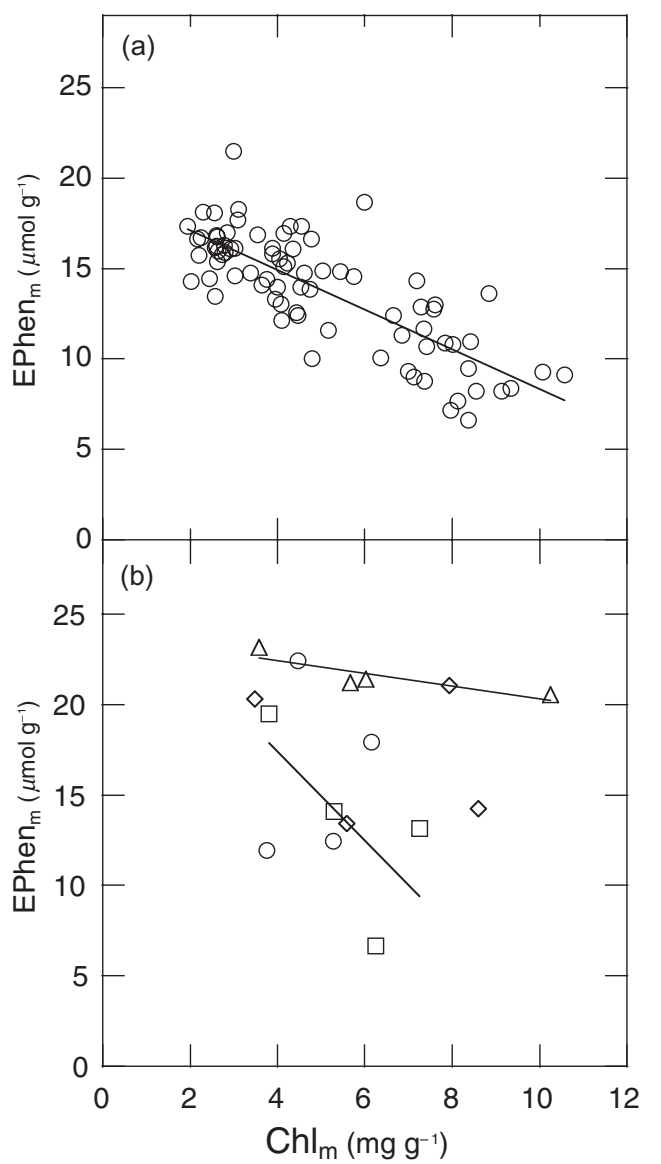

Figure 4. Relationship between mass-based EPhen and massbased Chl for $\operatorname{Exp} 1$ (a) and $\operatorname{Exp} 2$ (b). The symbols are: $\bigcirc$, Fagus sylvatica; $\triangle$, Betula pendula; $\diamond$ Acer pseudoplatanus; $\square$ Fraxinus excelsior. The regression equations are: (a) $\operatorname{EPhen}_{\mathrm{m}}=19.30-$ $1.09 * \mathrm{Chl}_{\mathrm{m}}, r^{2}=0.63, n=79, P<0.0001$; (b) Betula pendula, $\mathrm{EPhen}_{\mathrm{m}}=23.81-0.35 * \mathrm{Chl}_{\mathrm{m}}, r^{2}=0.75, n=4, P=0.1345 ; F$. excelsior, EPhen $\mathrm{m}_{\mathrm{m}}=27.24-2.46 * \mathrm{Chl}_{\mathrm{m}}, r^{2}=0.47, n=4, P=0.3128$. The correlation was not significant for $F$. sylvatica and $A$. pseudoplatanus of Exp 2. 
Table 1. $F$-values, d.f. (numerator, denominator) and significance of the ANOVAs for nitrogen treatment, plant age and species effects on LMA $\left(\mathrm{g} \mathrm{m}^{-2}\right), \mathrm{Chl}_{\mathrm{a}}\left(\mathrm{mg} \mathrm{m}^{-2}\right), \mathrm{Chl}_{\mathrm{m}}\left(\mathrm{mg} \mathrm{g}^{-1}\right), \operatorname{EPhen}_{\mathrm{a}}(\mu \mathrm{mol}$ $\left.\mathrm{cm}^{-2}\right)$ and $\operatorname{EPhen}_{\mathrm{m}}\left(\mu \mathrm{mol} \mathrm{g}^{-1}\right)$

\begin{tabular}{|c|c|c|c|c|c|c|}
\hline & \multicolumn{2}{|c|}{ Nitrogen effect } & \multicolumn{2}{|c|}{ Plant age effect } & \multicolumn{2}{|c|}{ Species effect } \\
\hline & d.f. & $F$ & d.f. & $F$ & d.f. & $F$ \\
\hline & $\begin{array}{l}{[p-1} \\
n-p]\end{array}$ & & $\begin{array}{l}{[p-1} \\
n-p]\end{array}$ & & $\begin{array}{l}{[p-1} \\
n-p]\end{array}$ & \\
\hline LMA & {$[1,167]$} & $103.8^{*}$ & {$[6,161]$} & $100.9^{*}$ & {$[3,164]$} & $908.0^{*}$ \\
\hline $\mathrm{Chl}_{\mathrm{a}}$ & {$[1,167]$} & $150.2 *$ & {$[6,161]$} & $16.3^{*}$ & {$[3,164]$} & $158.1 *$ \\
\hline $\mathrm{Chl}_{\mathrm{m}}$ & {$[1,167]$} & $110.1^{*}$ & {$[6,161]$} & $11.9^{*}$ & {$[3,164]$} & $182.8^{*}$ \\
\hline EPhen $_{\mathrm{a}}$ & {$[1,118]$} & $281.1^{*}$ & {$[4,113]$} & $7.7 *$ & {$[3,116]$} & $13.9 *$ \\
\hline EPhen $_{\mathrm{m}}$ & {$[1,117]$} & $2.1 \mathrm{NS}$ & {$[4,112]$} & $52.7 *$ & {$[3,115]$} & $367.2 *$ \\
\hline
\end{tabular}

$* P<0.001$.

Data are from Exp 3.

d.f., degrees of freedom; ANOVA, analysis of variance; NS, nonsignificant; $n$, total sample size; $p$, number of groups.

decreased when LMA increased from one species to another and as the plant aged. This was explained by a dilution effect due to an accumulation of dry matter.

The effects of nitrogen deficiency were moderate. $\mathrm{Chl}_{\mathrm{a}}$ and $\mathrm{Chl}_{\mathrm{m}}$ significantly decreased, whereas EPhen $_{\mathrm{a}}$ significantly increased by about $15 \%$ (Table 1 , Fig. 6). The decrease in $\mathrm{Chl}_{\mathrm{a}}$ is the result of the $\mathrm{Chl}_{\mathrm{m}}$ decline, which more than compensated for the increase in LMA. Lagerstroemia was the most affected by nitrogen deficiency (Fig. 6a). The increase in EPhen $_{\mathrm{a}}$ can be ascribed to LMA, which increased more than $\mathrm{EPhen}_{\mathrm{m}}$ in response to nitrogen deficiency (Fig. 6c \& d). When all EPhen ${ }_{m}$ data were taken into account, there were no significant influences of nitrogen deficiency (Table 1). But EPhen $\mathrm{m}_{\mathrm{m}}$ was significantly increased under nitrogen deficiency in the LMA range from 60 to $150 \mathrm{~g} \mathrm{~m}^{-2}(P<0.0001, n=41)$ (Fig. 6d). EPhen ${ }_{\mathrm{m}}$ depended on the species and decreased with plant ageing (Table 1).

Figure $7 \mathrm{a}$ shows that $\mathrm{Chl}_{\mathrm{m}}$ was positively correlated to $\mathrm{N}_{\mathrm{m}}$ with a unique relationship whatever the species, the treatment or the leaf age. EPhen ${ }_{\mathrm{m}}$ was significantly corre- lated to $\mathrm{Chl}_{\mathrm{m}}(P<0.0001)$ and was significantly higher in nitrogen-deficient plants $(P<0.001$, for the slope and for the Y-intercept) (Fig. 7b). Despite the constitutive difference in $\mathrm{Chl}_{\mathrm{m}}$ and $\mathrm{EPhen}_{\mathrm{m}}$ between the four species, $\mathrm{Chl}_{\mathrm{m}}$ and $\mathrm{EPhen}_{\mathrm{m}}$ varied in a unique manner with LMA (Fig. 6) and hence, were strongly correlated to each other (Fig. 7b). Still, as expected, this $\mathrm{EPhen}_{\mathrm{m}}$ versus $\mathrm{Chl}_{\mathrm{m}}$ relationship was under the influence of the nitrogen treatment. In the four species, $\mathrm{Chl}_{\mathrm{m}}$ and $\mathrm{EPhen}_{\mathrm{m}}$ decreased with plant ageing (arrows in Fig. 7).

\section{DISCUSSION}

Our experiments showed that $\mathrm{Chl}_{\mathrm{m}}$ and $\mathrm{EPhen}_{\mathrm{m}}$ varied with LMA in two different manners: (1) $\mathrm{Chl}_{\mathrm{m}}$ decreased and EPhen $_{\mathrm{m}}$ increased with LMA when irradiance and nitrogen availability induced LMA variations. As a matter of fact, LMA, Chl ${ }_{\mathrm{m}}$ and $\mathrm{EPhen}_{\mathrm{m}}$ displayed a large phenotypic plasticity with irradiance and to a lower extent with $\mathrm{N}$ availability; and (2) $\mathrm{Chl}_{\mathrm{m}}$ and $\mathrm{EPhen}_{\mathrm{m}}$ decreased in parallel when plant ageing increased LMA. In addition to this phenotypic plasticity, we found similar trends among species with different values of LMA, under similar conditions.

In our case, and in accordance with the PCM, high irradiance and/or nitrogen deficiency affected PHE allocation as detected by a decrease in $\mathrm{Chl}_{\mathrm{m}}$ concomitant to an increase in EPhen $_{\mathrm{m}}$. Due to acclimation to high irradiance, leaves are expected to allocate less nitrogen to light-harvesting protein complexes (on a mass basis), and more to photosynthetic electron transport components and to soluble proteins, like ribulose 1.5-bisphosphate carboxylase/oxygenase (Rubisco) (Boardman 1977; Evans 1989a; Evans \& Seemann 1989; Niinemets \& Tenhunen 1997). Decreasing $\mathrm{Chl}_{\mathrm{m}}$ with increasing irradiance is therefore a well-known process. Light induces the expression of PAL and chalcone synthase (Krizek et al. 1993), the latter being mainly stimulated by UV-B (Fuglevand, Jackson \& Jenkins 1996), therefore PHE demand for Phen synthesis increases (Jones \& Hartley 1999). Irradiance increases leaf area-based content of soluble Phen, which are mainly accumulated in the

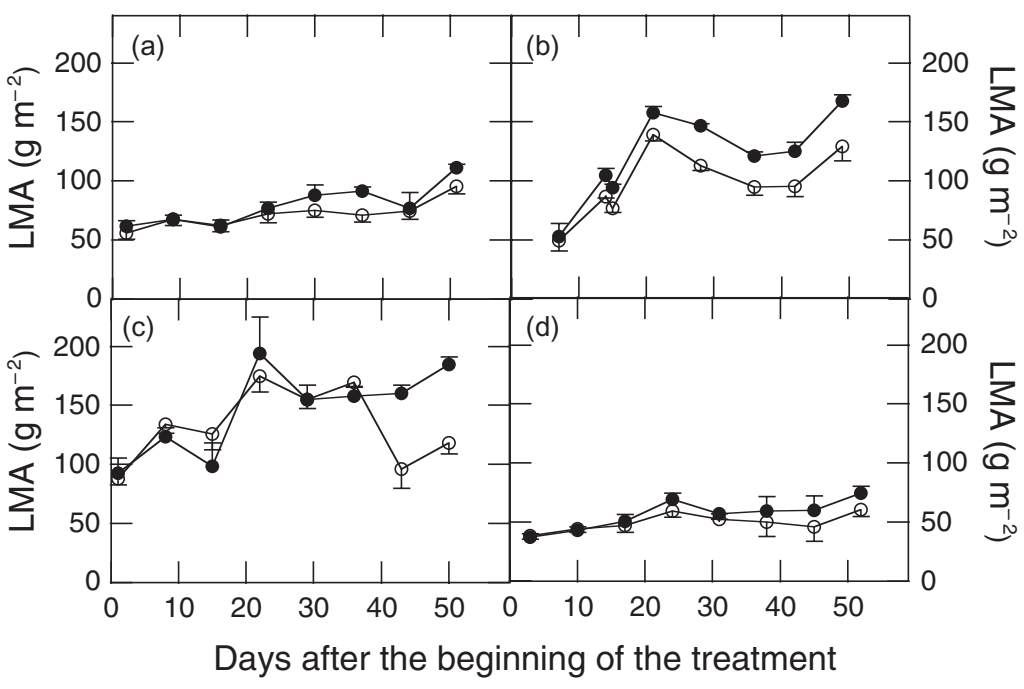

Figure 5. Time course of LMA after the beginning of the treatment for fertilized $(\bigcirc)$ and nitrogen-deficient $(\bullet)$ Callicarpa bodinieri cv. Profusion (a), Lagerstroemia indica cv. Red Imperator (b), Viburnum tinus cv. Macrocarpa (c) and Robinia pseudacacia cv. Casque Rouge (d). Data are from Exp 3. Means \pm SD are indicated, $n=3$ replicates of 20 leaves from two plants. SD, standard deviation. 


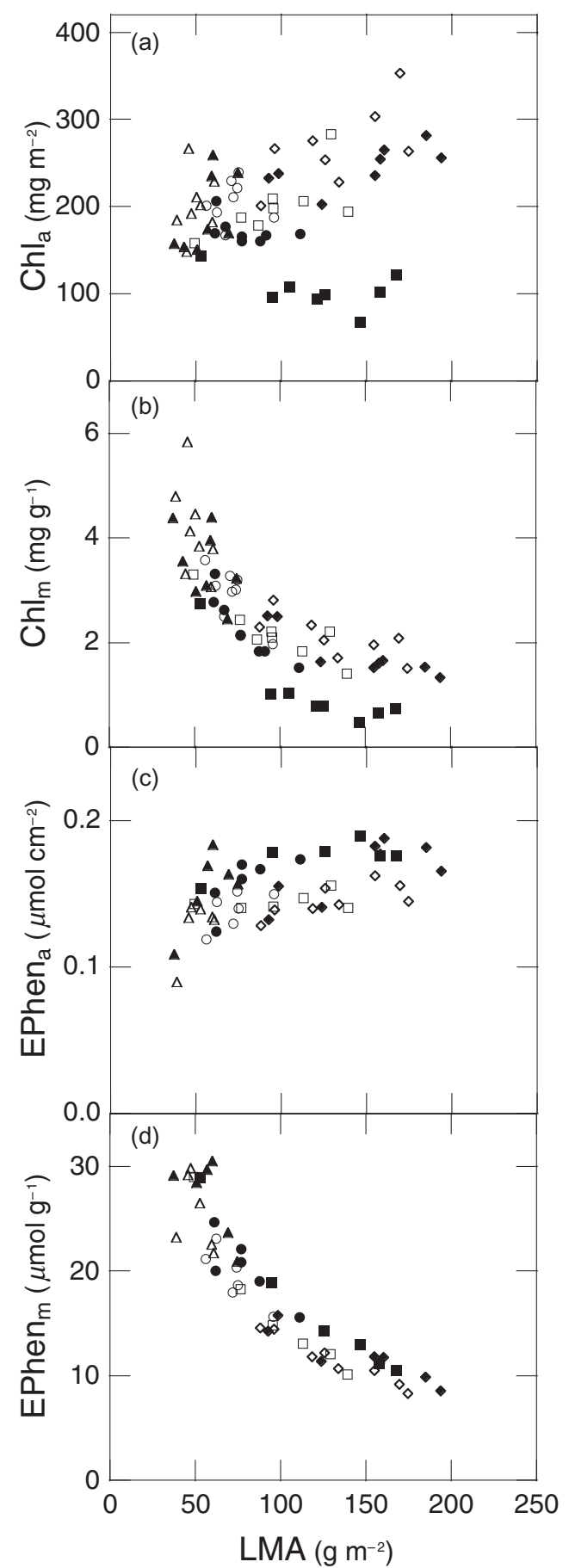

Figure 6. Relationships between the optical measurements of Chl $(\mathrm{a}, \mathrm{b})$ and EPhen $(\mathrm{c}, \mathrm{d})$ and LMA for Callicarpa bodinieri $(\mathrm{O})$, Lagerstroemia indica $(\square)$, Robinia pseudacacia $(\triangle)$ and Viburnum tinus $(\diamond)$ grown on fertilized (open symbols) or nitrogen-deficient (closed symbols) soil. (a,c) Area-based data obtained directly from optical measurements. (b,d) Mass-based data obtained after dividing optical measurements by LMA.

epidermis (Lovelock, Clough \& Woodrow 1992; Wand 1995; Liakoura et al.2003). As opposed to shade leaves, sun leaves typically exhibit a high photosynthetic capacity (Niinemets \& Tenhunen 1997); therefore, they have a high carbon input, which can exceed the demand for protein synthesis and can stimulate Phen synthesis (Bryant et al. 1983). All this favours a higher leaf $\mathrm{EPhen}_{\mathrm{m}}$ under higher irradiance. According to our results, leaf acclimation to light climate occurred through adjustment of leaf structure, leaf Chl content and UV-A absorption by EPhen, in agreement with many authors (Boardman 1977; Lovelock et al. 1992; Tegelberg et al. 2004). A decrease in leaf area, with an increase in epidermal UV-absorbers and a decrease in Chl content in sun leaves, limit the absorption of visible and UV radiations by the leaf, and therefore protect the mesophyll from photodestructive processes. Epidermal flavonoids, especially quercetin, may also act as antioxidants. They might cooperate with the ascorbate cycle to scavenge the hydrogen peroxide which leaks out from mesophyll cells where it is produced in response to an excess of light-energy excitation (Yamasaki, Sakihama \& Ikehara 1997).

Low nitrogen, under high irradiance, moderately affected LMA and optical measurements in our experiments. This is in agreement with the work of Koricheva et al. (1998) who studied a wide range of woody species, and with that of Pinto et al. (1999) reporting a sharp decrease in $\mathrm{Chl}_{\mathrm{a}}$ and a moderate increase in UV-B absorbing compounds in nitrogen-deficient bean from an unshaded greenhouse. On the one hand, nitrogen is preferentially allocated to Rubisco under high light and less to Chl-binding proteins. Therefore, nitrogen deficiency mainly reduces Rubisco concentration (Hikosaka \& Terashima 1995). This could explain the moderate effect of nitrogen deficiency on $\mathrm{Chl}_{\mathrm{m}}$. A larger effect could be expected at low irradiance. On the other hand, carbon input is expected to be reduced in nitrogen-deficient plants because of a reduction of photosynthesis (Reich, Walters \& Ellsworth 1991; Price et al. 1999), which could explain the only moderate increase in Phen content with nitrogen deficiency. Under low light, almost no increase in Phen is then expected under nitrogen deficiency as was found by Lovelock et al. (1992) for mangrove seedlings from a lowlight environment. In the framework of the PCM, low nitrogen under high light reduces the PHE demand for protein synthesis. PAL expression is expected to remain high, allowing PHE allocation to Phen, as long as photosynthetic capacity is only moderately limited by nitrogen deficiency. So, proteins accumulate at a slower rate and Phen at a higher rate under nitrogen limitation than when there is no limitation. A dry mass accumulation due to starch and cellulose accumulation would then affect more Prot $_{t}$ than EPhen $n_{t}$. Consequently, Prot $_{t}$ decreases whereas $\mathrm{Phen}_{\mathrm{t}}$ increases under low nitrogen availability, like they do under high light. Under these conditions, leaf sclerophylly should increase according to the nutritional basis of sclerophylly given by Loveless (1961). This strategy of leaf construction is usually associated with a reduced leaf area, a longer leaf life span and a high protection level against pathogen and herbivore attacks by large Phen contents (Herms \& Mattson 1992). This illustrates a case where resources are more allocated to defence than growth of the shoot (Herms \& Mattson 1992). 

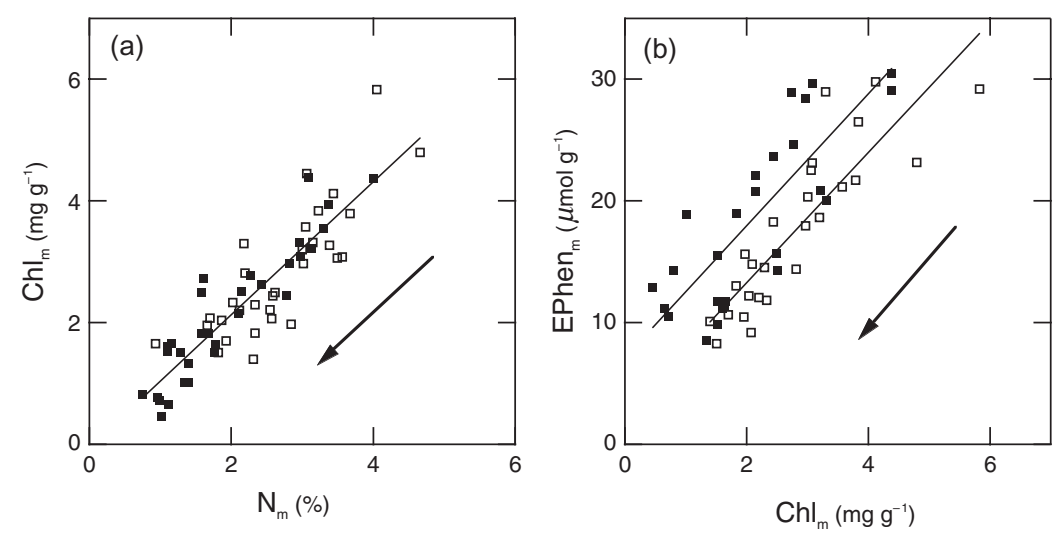

Figure 7. Relationship between $\mathrm{Chl}_{\mathrm{m}}$ and $\mathrm{N}_{\mathrm{m}}$ (a) and between $\mathrm{EPhen}_{\mathrm{m}}$ and $\mathrm{Chl}_{\mathrm{m}}$ (b) in fertilized (open symbol) and nitrogen-deficient (closed symbols) conditions. The data are from Exp 3 with the four species pooled together. The regression equations are: (a) $\mathrm{Chl}_{\mathrm{m}}=$ $-0.05+1.09 * \mathrm{~N}_{\mathrm{m}}, r^{2}=0.78, n=62, P<0001$; (b) $\mathrm{EPhen}_{\mathrm{m}}=5.35 * \mathrm{Chl}_{\mathrm{m}}+2.56, r^{2}=0.74, n=25$, $P<0.00001$ and EPhen $_{\mathrm{m}}=5.42 * \mathrm{Chl}_{\mathrm{m}}+7.08$, $r^{2}=0.67, n=25, P<0.0001$ for fertilized and nitrogen-deficient conditions, respectively. The arrow indicates increasing plant age.
In a second case, plant ageing and differences in leaf construction among woody species affect more leaf dry mass content than competition for PHE allocation between protein and Phen. This is detected by a simultaneous decrease in $\mathrm{Chl}_{\mathrm{m}}$ and $\mathrm{EPhen}_{\mathrm{m}}$ with LMA increase, due to a dilution by dry mass accumulation. This dilution effect explains the results of Schultz, Nothnagle \& Baldwin (1982) showing a sharp decline in nitrogen content and a moderate decrease in Phen $_{\mathrm{t}}$ in leaves of yellow birch throughout the growing season. Dilution effects occur in general when photosynthesis supplies carbon in excess to the growth demand (Jones \& Hartley 1999).

The agreement of our results with PCM suggests that the optical measurements of $\mathrm{EPhen}_{\mathrm{a}}$ and $\mathrm{Chl}_{\mathrm{a}}$, after transformation into mass contents by dividing by LMA, could be used as relative indicators of $\mathrm{Phen}_{\mathrm{t}}$ and $\operatorname{Prot}_{\mathrm{t}}$ (Fig. 8). Indeed, Peng et al. (1993) have shown earlier on rice that SPAD measurements transformed into $\mathrm{Chl}_{\mathrm{m}}$ are proportional to $\mathrm{N}_{\mathrm{m}}$, and the latter is a good representative of the leaf mass-based protein content (Evans 1989a; Takashima et al. 2004).

The relationship between EPhen $_{\mathrm{a}}$ and $\mathrm{Phen}_{\mathrm{t}}$ was less clear. Optical measurements of EPhen ${ }_{\mathrm{a}}$ depend on the UV absorption of both soluble Phen (flavonoids) and cell wallbound Phen (hydroxycinnamic acids) (Goulas et al. 2004). Due to the use of $375 \mathrm{~nm}$ light, the EPhen sensed by Dualex will be mainly the derivatives of the flavonols kaempferol, quercetin and myricetin with maximum absorption in UVA at 367,370 and $378 \mathrm{~nm}$, respectively, and to a much smaller extent other flavonoids and hydroxycinnamic acids (Cerovic et al. 2002). On the other hand, EPhen $\mathrm{m}_{\mathrm{m}}$ may vary more than Phen $_{\mathrm{t}}$ because partitioning among the various Phen compounds within leaves may vary according to environment (see Tegelberg et al. 2004). Still, although the leaf flavonoid content is highly sensitive to biotic and abiotic control of PAL expression (Margna 1977), the results of Waterman et al. (1984) and Mole et al. (1988) showed a parallel variation of soluble Phen and condensed tannins under different irradiance levels.

We showed the importance of quantifying LMA in order to understand resource allocation to Phen and protein from area-based optical measurements. What is missing now is a non-destructive optical indicator of LMA to be able to assess the allocation issues fully and non-destructively. A lead towards that goal could be the use of leaf transmission in the infrared (Pavan et al. 2004). Due to the strong correlation between LMA and EPhen ${ }_{a}$ in the situation where light is controlling leaf anatomy, EPhen ${ }_{a}$ could also be used as a surrogate for LMA in order to analyse $\mathrm{Chl}_{\mathrm{a}}, \mathrm{Chl}_{\mathrm{m}}, \mathrm{N}_{\mathrm{m}}$ and $\mathrm{N}_{\mathrm{a}}$ relationships. Alternatively, the $\mathrm{Chl}_{\mathrm{a}} / \mathrm{EPhen}_{\mathrm{a}}$ ratio,

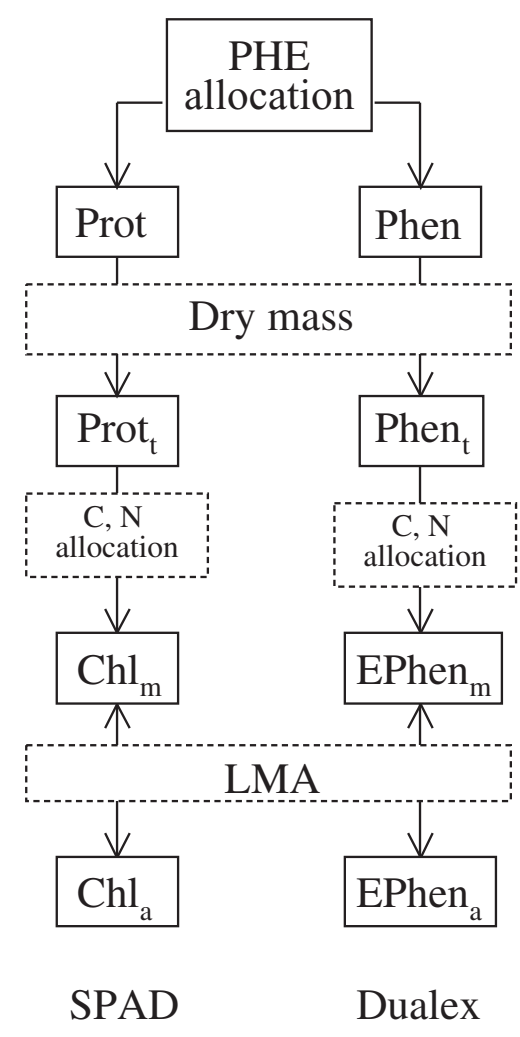

Figure 8. Meaning of Minolta SPAD-502 (SPAD) and Dualex measurements in the frame of the PCM (Jones \& Hartley 1999).

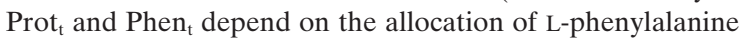
(PHE) and dry matter accumulation. Depending on optimization of intraleaf allocation of resources, Chl present in Chl-binding proteins complexes $\left(\mathrm{Chl}_{\mathrm{m}}\right)$ and $\mathrm{EPhen}_{\mathrm{m}}$ will be different. SPAD and Dualex measure $\mathrm{Chl}_{\mathrm{a}}$ and $\mathrm{EPhen}_{\mathrm{a}}$, respectively, which can be transformed into per mass contents $\left(\mathrm{Chl}_{\mathrm{m}}\right.$ and $\left.\mathrm{EPhen}_{\mathrm{m}}\right)$ after division by LMA. Prot, protein. 
which eliminates the need for LMA knowledge, can be used to estimate $\mathrm{Chl}_{\mathrm{m}} / \mathrm{EPhen}_{\mathrm{m}}$, and by extension the Prot/ Phen ratio to analyse allocation issues. It seems from the results presented here in conjunction with recent results on Phen intraannual dynamics (Riipi et al. 2002) that the Prot/ Phen ratio is more of an interannual leaf trait defined by the light and nitrogen availability at leaf set-up. To detect a small increase in EPhen $_{\mathrm{a}}$ due to $\mathrm{N}$-deficiency in wheat, a large number of samples had to be acquired (Cartelat et al. 2005). Rapid optical measurement allows this statistical approach and therefore could be used for a better estimate of the degree of $\mathrm{N}$-deficiency in woody species.

\section{ACKNOWLEDGMENTS}

This work was supported by the CNRS through the GDR 1536 'FLUOVEG' and by GIP ECOFOR and Region Lorraine through support of the experiment testing sapling development under different levels of irradiance. We thank Jacqueline Marchand (UMR INRA-UHP Ecologie et Ecophysiologie Forestières, Champenoux, France) and Monique Sigogne (UMR SAGAH, France) for nitrogen analysis, and Jean-Marie Gioria (UMR INRA-UHP Ecologie et Ecophysiologie Foristières, Champenoux, France) for raising the plants and managing the controlled shade experiment. We also thank E. Dufrêne (ESE, Orsay, France), R. Boumaza (UMR SAGAH, France) and K. Soudani (ESE, Orsay, France) for helpful comments on the manuscript.

\section{REFERENCES}

Aranda I., Pardo F., Gil L. \& Pardos J.A. (2004) Anatomical basis of the change in leaf mass per area and nitrogen investment with relative irradiance within canopy of eight temperate tree species. Acta Oecologica 25, 187-195.

Barnes J.D., Balaguer L., Manrique E., Elvira S. \& Davison A.W. (1992) A reappraisal of the use of DMSO for the extraction and determination of chlorophylls a and $\mathrm{b}$ in lichens and higher plants. Environmental Experimental Botany 32, 85-100.

Bate-Smith E.C. (1962) The phenolic constituents of plants and their taxonomic significance. Journal of Linnean Society of Botany $\mathbf{5 8}, 95-175$.

Boardman N.K. (1977) Comparative photosynthesis of sun and shade plants. Annual Review of Plant Physiology 28, 355377.

Bryant J.P., Chapin F.S. III \& Klein D.R. (1983) Carbon/nutrient balance of boreal plants in relation to vertebrate herbivory. Oikos 40, 357-368.

Cartelat A., Cerovic Z.G., Goulas Y., Meyer S., Lelarge C., Prioul J.L., Barbottin A., Jeuffroy M.H., Gate P., Agati G. \& Moya I. (2005) Optically assessed contents of leaf polyphenolics and chlorophyll as indicators of nitrogen deficiency in wheat (Triticum aestivum L.). Field Crop Research 91, 35-49.

Cerovic Z.G., Ounis A., Cartelat A., Latouche G., Goulas Y., Meyer S. \& Moya I. (2002) The use of chlorophyll fluorescence excitation spectra for the nondestructive in situ assessment of UV-absorbing compounds in leaves. Plant, Cell and Environment 25, 1663-1676.

Coste S., Roggy J.C., Imbert P., Born C., Bonal D. \& Dreyer E. (2005) Diversity in leaf traits related to photosynthesis among seedlings from 14 rainforest tree species: is there a relationship with ecological grouping of the species? Tree Physiology 25, 1127-1137.

Evans J.R. (1989a) Partitioning of nitrogen between and within leaves grown under different irradiances. Australian Journal of Plant Physiology 16, 533-548.

Evans J.R. (1989b) Photosynthesis and nitrogen relationships in leaves of C3 plants. Oecologia 78, 9-19.

Evans J.R. \& Poorter H. (2001) Photosynthetic acclimation of plants to growth irradiance: the relative importance of specific leaf area and nitrogen partitioning in maximizing carbon gain. Plant, Cell and Environment 24, 755-767.

Evans J.R. \& Seemann J.R. (1989) The allocation of protein nitrogen in the photosynthetic apparatus: costs, consequences, and control. In Photosynthesis (ed. R. Alan), pp. 183-205. Liss, Inc, New York, NY, USA.

Fuglevand G., Jackson J.A. \& Jenkins G.I. (1996) Light signal transduction pathways interact synergistically to regulate chalcone synthase gene expression in Arabidopsis. Plant Cell 8, 2347-2357.

Gershenzon J. (1994) The cost of plant chemical defense against herbivory: a biochemical perspective. In Insect-Plant Interactions (ed. A. Bernays) Vol 5, pp. 105-173. CRC Press, Boca Raton, FL, USA.

Goulas Y., Cerovic Z.G., Cartelat A. \& Moya I. (2004) Dualex: a new instrument for field measurements of epidermal ultraviolet absorbance by chlorophyll fluorescence. Applied Optics 43, $4488-4496$.

Granier A., Pilegaard K. \& Jensen N.O. (2002) Similar net ecosystem exchange of beech stands located in France and Denmark. Agricultural and Forest Meteorology 114, 75-82.

Hanson H.C. (1917) Leaf-structure as related to environment. American Journal of Botany 4, 533-560.

Henkes S., Sonnewald U., Badur R., Flachmann R. \& Stitt M. (2001) A small decrease of plastid transketolase activity in antisense tobacco transformants has dramatic effects on photosynthesis and phenylpropanoid metabolism. Plant Cell 13, 535-551.

Herms D.A. \& Mattson W.J. (1992) The dilemma of plants: to grow or to defend. Quaterly Review of Biology 67, 287-290.

Hikosaka K. \& Terashima I. (1995) A model of the acclimation of photosynthesis in the leaves of $\mathrm{C} 3$ plants to sun and shade with respect to nitrogen uses. Plant, Cell and Environment 18, 605618.

Jones C.G. \& Hartley S.E. (1999) A protein competition model for phenolic allocation. Oikos 86, 27-44.

Kolb C.A. \& Pfündel E.E. (2005) Origins of non-linear and dissimilar relationships between epidermal UV absorbance and UV absorbance of extracted phenolics in leaves of grapevine and barley. Plant, Cell and Environment 25, 580-590.

Koricheva J., Larsson S., Haukioja E. \& Keinänen M. (1998) Regulation of woody plant secondary metabolism by resource availability: hypothesis testing by means of meta-analysis. Oikos 83, 212-226.

Krizek D.T., Kramer G.F., Upadhayaya A. \& Mirecki R.M. (1993) UV-B response of cucumber seedlings grown under metal halide and high pressure sodium/deluxe lamps. Physiologia Plantarum 88, 350-358.

Lavola A., Julkunen-Tiitto R., de la Rosa T., Lehto T. \& Aphalo P.J. (2000) Allocation of carbon to growth and secondary metabolites in birch seedlings under UV-B radiation and $\mathrm{CO}_{2}$ exposure. Physiologia Plantarum 109, 260-267.

Liakoura V., Bornman J.F. \& Karabourniotis G. (2003) The ability of abaxial and adaxial epidermis of sun and shade leaves to attenuate UV-A and UV-B radiation in relation to the UV absorbing capacity of the whole leaf methanolic extract. Physiologia Plantarum 117, 33-43. 
Lichtenthaler H. (1987) Chlorophylls and carotenoids: pigments of photosynthetic biomembranes. Methods in Enzymology 148, 350-382.

Loveless A.R. (1961) A nutritional interpretation of sclerophylly based on differences in the chemical composition of sclerophyllous and mesophytic leaves. Annals of Botany 25, 168-184.

Lovelock C.E., Clough B.F. \& Woodrow I.E. (1992) Distribution and accumulation of ultraviolet-radiation-absorbing compounds in leaves of tropical mangroves. Planta 188, 143-154.

Margna U. (1977) Control at the level of substrate supply - An alternative in the regulation of phenylpropanoid accumulation in plant cells. Phytochemistry 16, 419-426.

Markwell J., Osterman J.C. \& Mitchell J.L. (1995) Calibration of the Minolta SPAD-502 leaf chlorophyll meter. Photosynthesis Research 46, 467-472.

Mole S., Ross J.A.M. \& Waterman P.G. (1988) Light-induced variation in phenolic levels in foliage of rain-forest plants. I. Chemical changes. Journal of Chemical Ecology 14, 1-21.

Niinemets Ü. (1995) Distribution of foliar carbon and nitrogen across the canopy of Fagus sylvatica: adaptation to a vertical light gradient. Acta Oecologica 16, 525-541.

Niinemets Ü. \& Tenhunen J.D. (1997) A model separating leaf structural and physiological effects on carbon gain along light gradients for the shade-tolerant species Acer saccharum. Plant, Cell and Environment 20, 845-866.

Niinemets Ü., Kull O. \& Tenhunen J.D. (2004) Within-canopy variation in the rate of development of photosynthetic capacity is proportional to integrated quantum flux density in temperate deciduous trees. Plant, Cell and Environment 27, 293-313.

Pavan G., Jacquemoud S., de Rosny G., Rambaut J.-P., Frangi J.P., Bidel L.P.R. \& François C. (2004) Ramis: a new portable field radiometer to estimate leaf biochemical content. In 7 th International Conference on Precision Agriculture and Other Precision Resources Management (ed. D.J. Mulla). Mineapolis, MN, USA (25-28 July 2004, pp. 1366-1379).

Peng S., Garcia F.V., Llaza R.C. \& Cassman K.G. (1993) Adjustment for specific leaf weight improves chlorophyll meter's estimate of rice leaf nitrogen concentration. Agronomy Journal 85, 987-990.

Pinto M.E., Casati P., Hsu T.P., Ku M.S.B. \& Edwards G.E. (1999) Effects of UV-B radiation on growth, photosynthesis, UV-Babsorbing compounds and NADP-malic enzyme in bean (Phaseolus vulgaris L.) grown under different nitrogen conditions. Journal of Photochemistry and Photobiology B Biology 48, 200-209.

Poorter H. (1994) Construction costs and payback time of biomass: a whole plant perspective. In $A$ Whole Plant Perspectives $C-N$ Interactions (eds J. Roy \& E. Garnier), pp. 111-127. SPB Academic Publishing, The Hague, the Netherlands.
Price P.W., Waring G.L., Julkunen-Tiitto R., Tahvanainen J., Mooney H.A. \& Craig T.P. (1999) Carbon-nutrient balance hypothesis in within-species phytochemical variation of Salix lasiolepis. Journal of Chemical Ecology 15, 1117-1131.

Reich P.B., Walters M.B. \& Ellsworth D.S. (1991) Leaf age and season influence the relationships between leaf nitrogen, leaf mass per area and photosynthesis in apple and oak trees. Plant, Cell and Environment 14, 251-259.

Riipi M., Ossipov V., Lempa K., Haukioja E., Koricheva J., Ossipova S. \& Pihlaja K. (2002) Seasonal changes in birch leaf chemistry: are there trade-offs between leaf growth and accumulation of phenolics? Oecologia 130, 380-390.

Scheible W.-R., Morcuende R., Czechowski T., Fritz C., Osuna D., Palacios-Rojas N., Schindelasch D., Thimm O., Udvardi M.K. \& Stitt M. (2004) Genome-wide reprogramming of primary and secondary metabolism, protein synthesis, cellular growth processes, and the regulatory infrastructure of Arabidopsis in response to nitrogen. Plant Physiology 136, 2483-2499.

Schultz J.C., Nothnagle P.J. \& Baldwin I.T. (1982) Seasonal and individual variation in leaf quality of two northern hardwoods tree species. American Journal of Botany 65, 753-759.

Takashima T., Hikosaka K. \& Hirose T. (2004) Photosynthesis or persistence: nitrogen allocation in leaves of evergreen and deciduous Quercus species. Plant, Cell and Environment 27, 1047-1054.

Tegelberg R., Julkunen-Tiitto R. \& Aphalo P.J. (2004) Red: farred light ratio and UV-B radiation: their effects on leaf phenolics and growth of silver birch seedlings. Plant, Cell and Environment 27, 1005-1013.

Wand S.J.E. (1995) Concentration of ultraviolet-B radiation absorbing compounds in leaves of a range of fynbos species. Vegetatio 116, 51-61.

Waterman P.G., Ross J.A.M. \& McKey D.B. (1984) Factors affecting levels of some phenolic compounds, digestibility, and nitrogen content of the mature leaves of Barteria fistulosa (Passifloraceae). Journal of Chemical Ecology 10, 387401.

Wink M. (1999) Functions of plant secondary metabolites and their exploitation in biotechnology. In Annual Plant Review (ed. M. Wink) Vol 3, pp. 1-15. Sheffield Academic Press, CRC Press, Sheffield, UK.

Witkowski E.T.F. \& Lamont B.B. (1991) Leaf specific mass confounds leaf density and thickness. Oecologia 88, 486-493.

Yamasaki H., Sakihama Y. \& Ikehara N. (1997) Flavonoidperoxidase reaction as a detoxification mechanism of plant cells against $\mathrm{H}_{2} \mathrm{O}_{2}$. Plant Physiology 115, 1405-1412.

Received 23 September 2005; received in revised form 11 February 2006; accepted for publication 20 February 2006 